\title{
Article \\ Tellurium Enrichment in Jurassic Coal, Brora, Scotland
}

\author{
Liam Bullock ${ }^{1, *}$ (D), John Parnell ${ }^{1}$, Magali Perez ${ }^{2}$ and Joerg Feldmann ${ }^{2}$ \\ 1 Department of Geology \& Petroleum Geology, Meston Building, University of Aberdeen, King's College, \\ Aberdeen AB24 3UE, UK; j.parnell@abdn.ac.uk \\ 2 Trace Element Speciation Laboratory (TESLA), Department of Chemistry, Meston Building, \\ University of Aberdeen, King's College, Aberdeen AB24 3UE, UK; magali.perez@abdn.ac.uk (M.P.); \\ j.feldmann@abdn.ac.uk (J.F.) \\ * Correspondence: liam.bullock@abdn.ac.uk; Tel.: +44-7789-585959
}

Received: 31 October 2017; Accepted: 21 November 2017; Published: 23 November 2017

\begin{abstract}
Mid-Jurassic pyritic coals exposed at the village of Brora, northern Scotland, UK, contain a marked enrichment of tellurium (Te) relative to crustal mean, average world coal compositions and British Isles Carboniferous coals. The Te content of Brora coal pyrite is more than one order of magnitude higher than in sampled pyrite of Carboniferous coals. The Te enrichment coincides with selenium (Se) and mercury $(\mathrm{Hg})$ enrichment in the rims of pyrite, and $\mathrm{Se} / \mathrm{Te}$ is much lower than in pyrites of Carboniferous coals. Initial pyrite formation is attributed to early burial (syn-diagenesis), with incorporation of $\mathrm{Te}, \mathrm{Se}, \mathrm{Hg}$ and lead $(\mathrm{Pb})$ during later pyrite formation. The source of Te may have been a local hydrothermal system which was responsible for alluvial gold $(\mathrm{Au})$ in the region, with some $\mathrm{Au}$ in Brora headwaters occurring as tellurides. Anomalous Te is not ubiquitous in coal, but may occur locally, and is detectable by laser ablation inductively coupled plasma-mass spectrometry (LA-ICP-MS).
\end{abstract}

Keywords: tellurium; coal; pyrite; Jurassic; selenium

\section{Introduction}

Due to its low abundance in the Earth's crust $\left(2 \mu \mathrm{g} \cdot \mathrm{kg}^{-1}\right)$ [1] and analytical limitations for low detection, tellurium (Te) is seldom recognised in many geological settings. Tellurium is typically associated with deep marine ferromanganese crusts [2-4] and as such has been considered as a target for deep sea mining operations. However, Te has been previously suggested to concentrate in low-temperature sedimentary environments, controlled by redox variations and forming inclusions in sulphide minerals and red bed successions $[5,6]$. This suggests that Te may locally concentrate across sediments. Due to the aforementioned analytical limitations, there are few published Te values in coal deposits, with virtually all Te previously measured in coal in fly ash [7-10], and average world concentration estimates achieved by fraction calculation from chemically-similar selenium (Se) abundance [11]. High Te concentrations in coal may be both an important environmental concern and an economic opportunity. For instance, Te in exposed coal seams, historic coal mining sites and associated tailings may pose a source of contamination, resulting in potentially toxic levels and a risk to soils, surface and groundwater systems. Tellurium is considered a contaminant in many ore refinery systems [12], and is classified as a toxic trace element in high concentrations [13-16], particularly in the form of tellurite [11,12]. The global trend in environmental awareness and need for low carbon energy sources has also led to an increasing interest in Te, essential in future green energy technologies [17-21], e.g., cadmium (Cd) telluride solar cells $[22,23]$. Therefore, accurate recognition of Te concentrations in coal is critical for a suitable assessment of coal as a potential Te host. This study reports the rare occurrence of elevated Te in pyritic banded Jurassic coals of Brora (northern Scotland), recognised by 
laser ablation inductively coupled plasma-mass spectrometry (LA-ICP-MS) methods. Results highlight the potential for concentrated Te in similar pyritic coals, and improved methods of Te detection in coals.

\section{Geological Setting}

Jurassic to Triassic sediments outcrop over a narrow coastal strip around the town of Brora in Sutherland, Inner Moray Firth, northern Scotland (Figure 1a). The Brora Coal Formation forms part of the interbedded Fladen Group (Mid Jurassic - Bathonian to Callovian in age; Figure 1b [24-27]). The Brora Coal Formation consists of heterolithic units of interbedded sandstones, mudstones and coals, lying between the Orrin Formation and the Beatrice Formation in the Inner Moray Firth [27]. The lower part of the Brora Coal Formation is cut by the Brora Fault [27]. The formation consists of two members: the Doll Member and overlying Inverbrora Member [28]. Sandstone units grade upwards into bioturbated mudstones and coaly zones at the top of the formation (the Brora Coal Unit). The coal is approximately $1 \mathrm{~m}$ thick, pyritic and blocky, with dull laminated bands [26], and also occurs as thin bands within mudstone units of varying proportions. The formation is interpreted as a product of coastal, alluvial and floodplain deposits [25,29,30], with Brora coal accumulating drifted plant material in a back-barrier silted-up lagoonal area. The Brora Coal Unit represents the onset of early Callovian transgression [26,31]. The region is well known for alluvial gold (Au) localities (Figure 1), with bedrock mineralisation $\sim 25 \mathrm{~km}$ west of the town of Brora [32,33].

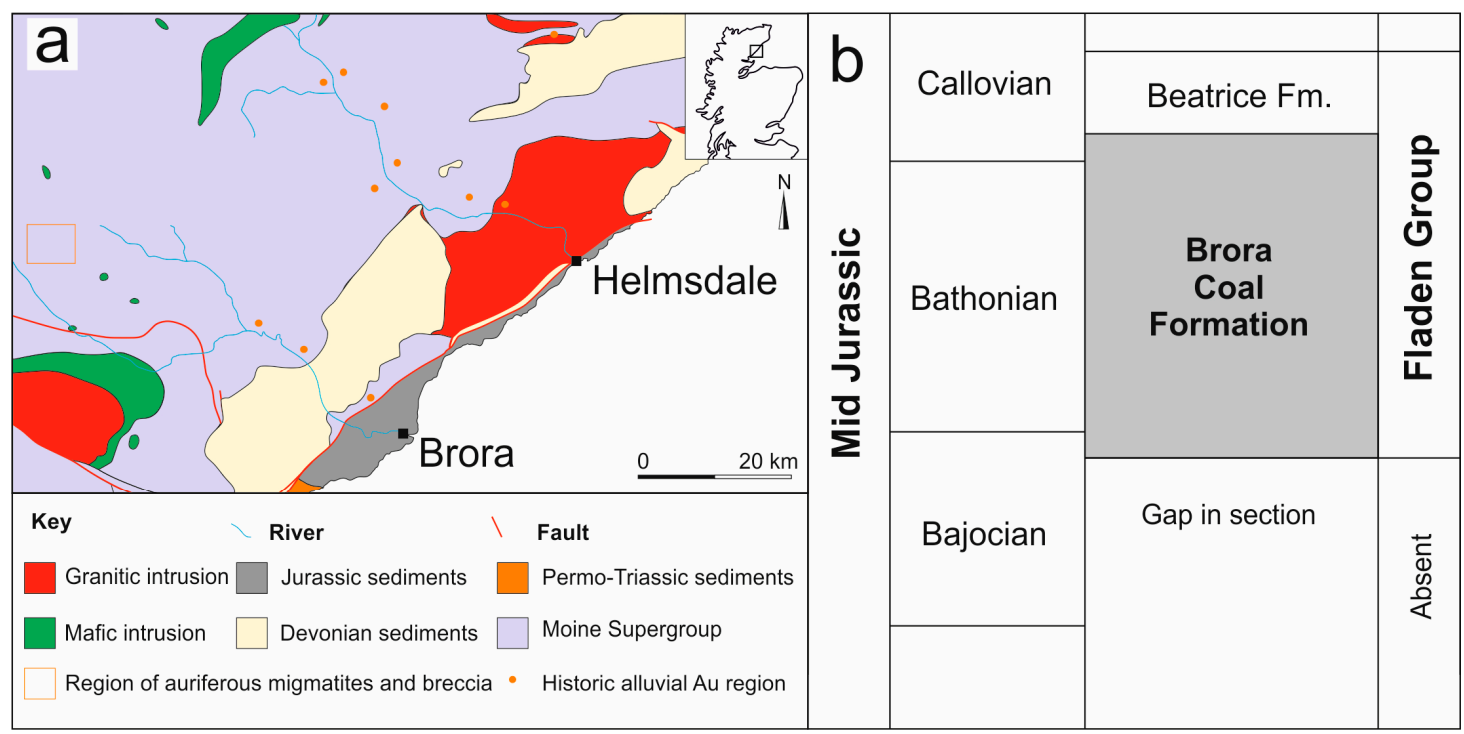

Figure 1. (a) Simplified geological map of the region surrounding the village of Brora in Sutherland, Inner Moray Firth, northern Scotland, adapted from [27,34]; and (b) lithostratigraphy of the Brora Coal Formation [27]. Historic alluvial Au localities and region of auriferous river bank deposits also shown $[32,33]$.

\section{Materials and Methods}

The Te and associated trace element content of whole rock Brora coal was determined as part of a suite of 51 elements using ICP-MS (Agilent, Santa Clara, CA, USA) techniques at ALS Minerals (Loughrea, Ireland). Samples were milled and homogenised, and $0.25 \mathrm{~g}$ was digested with aqua regia in a graphite heating block. The residue was diluted with deionised water, mixed and analysed using a Varian 725 instrument (Method code: ME-MS41). Results were corrected for spectral inter-element interferences. Measurement of four standards fell within pre-defined targets, and duplicate analyses for blanks, standards and repeat samples were all within $1 \%$ of each other. For LA-ICP-MS mapping, transecting and quantification of pyrite in Brora coal, trace element analysis 
was performed using a New Wave Research laser ablation system UP $213 \mathrm{~nm}$ coupled to an ICP-MS Agilent 7900. Sample mapping was performed at a $10 \mathrm{~Hz}$ repetition rate, a spot size of $100 \mu \mathrm{m}$ and an ablation speed of $50 \mu \mathrm{m} \cdot \mathrm{s}^{-1}$. Each ablation was preceded by $15 \mathrm{~s}$ warm up, with a delay of $15 \mathrm{~s}$ applied between each ablation. The following isotopes were monitored (dwell time): ${ }^{57} \mathrm{Fe}(0.001 \mathrm{~s})$, ${ }^{65} \mathrm{Cu}(0.001 \mathrm{~s}){ }^{75} \mathrm{As}(0.05 \mathrm{~s}),{ }^{78} \mathrm{Se}(0.1 \mathrm{~s}),{ }^{82} \mathrm{Se}(0.1 \mathrm{~s}),{ }^{107} \mathrm{Ag}(0.1 \mathrm{~s}),{ }^{125} \mathrm{Te}(0.1 \mathrm{~s}),{ }^{126} \mathrm{Te}(0.1 \mathrm{~s}),{ }^{197} \mathrm{Au}(0.1 \mathrm{~s})$, ${ }^{202} \mathrm{Hg}(0.1 \mathrm{~s}),{ }^{208} \mathrm{~Pb}(0.05 \mathrm{~s})$ and ${ }^{209} \mathrm{Bi}(0.1 \mathrm{~s})$. NIST Glass 612 (NIST Gaithersburg MD) was used to optimise the ICP-MS parameters in order to reach the maximum sensitivity and to guarantee a low oxide formation. Quantification was performed by using the reference material MASS-1 Synthetic Polymetal Sulfide (USGS, Reston, VA, USA). The ratio concentration $\left(\mu \mathrm{g} \cdot \mathrm{g}^{-1}\right) /$ counts per seconds was calculated from the standard MASS-1 and multiplied by the sample counts. For comparison, select pyritic British and Irish Carboniferous coals were also analysed by LA-ICP-MS. Carboniferous coals include: Castlecomer (County Kilkenny, Ireland), Row Brook (W Midlands, England), Wemyss (Fifeshire, Scotland), Apedale (Staffordshire, England) and Greenburn (Ayrshire, Scotland).

\section{Results}

Brora coals show a dark brown to dull black lustre, are soft and break up easily, typical of subbituminous ranking coals. Brora coals host pyrite, both as sporadic isolated, framboidal pyrite, and more typically in continuous bands. Coal whole rock Te concentrations are $0.04-0.11 \mathrm{ppm}$, higher than the world average coal content of $0.015 \mathrm{ppm}$ (estimated average [11]) and average continental crust value of $0.002 \mathrm{ppm}$ [1]. Brora coal whole rock sulphur (S) content is high (7.2-7.8\%). Here, high $\mathrm{S}$ content is defined as $>1.3 \%$, the cut-off value for the $\mathrm{S}$ content of coals acceptable for local power generation [35]. Despite elevated Te compared to the world coal average, chemically-associated Se content is 2.1-3.2 ppm, consistent with world average Se coal content of 1.6-3 ppm [36-38] and British Carboniferous Se coal content $[36,38,39]$. Whole rock silver $(\mathrm{Ag})$ content is low $(0.03-0.06 \mathrm{ppm}$ compared to world coal average of $0.09 \mathrm{ppm}$ [38]), and $\mathrm{Au}$ is below level of detection (0.2 ppm). Lead $(\mathrm{Pb})$ is higher than the world coal average (17.2-35.1 ppm compared to world average $7.8 \mathrm{ppm}$ [40]), as is copper (Cu) (17.9-28.4 ppm compared to world average $16 \mathrm{ppm}$ [40]).

The pyritic phase of sampled Brora coal is shown in LA-ICP-MS maps and line transect plots by elevated Fe content, forming a vertical band through the centre of the map and the main peak in plots (Figures 2-6). All trace elements concentrate higher in the pyritic band compared to the coal matrix, with higher relative abundance indicated by background corrected signal intensities (CPS axis) compared to the coal matrix. LA-ICP-MS mapping indicates Te content of up to $6 \mathrm{ppm}$ towards the edges of the pyrite, with an overall Te pyrite content of 1.8-2.9 ppm (Table 1; comparative Carboniferous coal pyrite data also shown). Figure 2 also shows $\mathrm{Cu}$ concentrations of $1000 \mathrm{ppm}$ in areas of the centre of pyrite, more typically up to $100 \mathrm{ppm}$, with an overall average of $126 \mathrm{ppm} \mathrm{Cu}$ in pyrite. Arsenic is higher in the centre of the pyrite, with an overall pyrite average of $37.1 \mathrm{ppm}$. Se averages $18 \mathrm{ppm}$ in pyrite $(n=3)$, and higher concentrations are more associated with the inner rim of pyrite, coinciding with higher Te concentrations. Mercury $(\mathrm{Hg})$ and $\mathrm{Pb}$ are also higher at the edge of pyrite, with an average $\mathrm{Hg}$ content of $5.1 \mathrm{ppm}$ in pyrite, and $\mathrm{Pb}$ average of $242.7 \mathrm{ppm}$. High concentrations of Te and Se are reflected in the line transect plots (Figures 3 and 4), showing high peaks coinciding with the edge of the pyrite. 
Brora sample

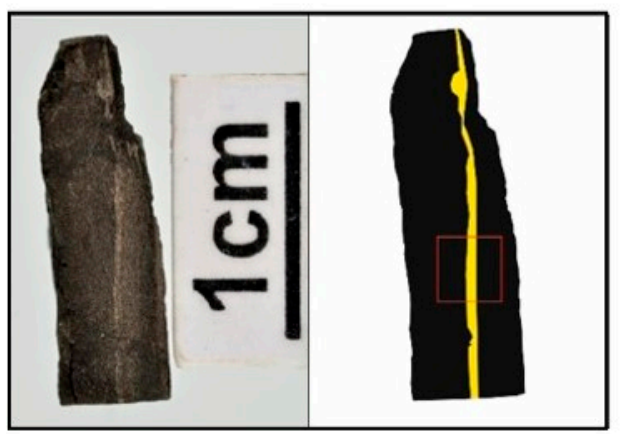

$\mathrm{Te}$

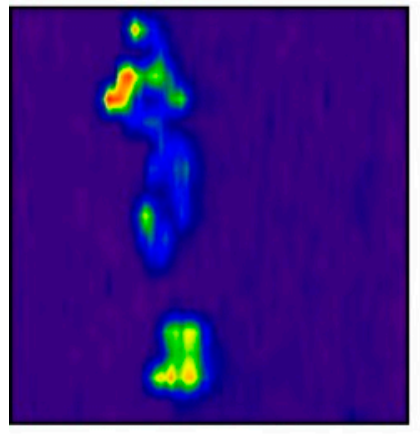

As

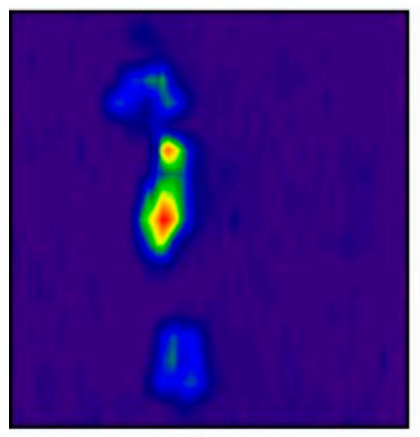

$\mathrm{Cu}$

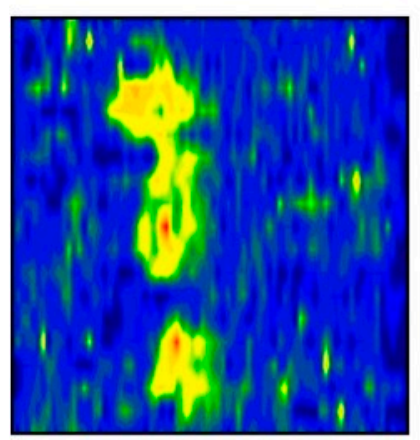

$\mathrm{Fe}$

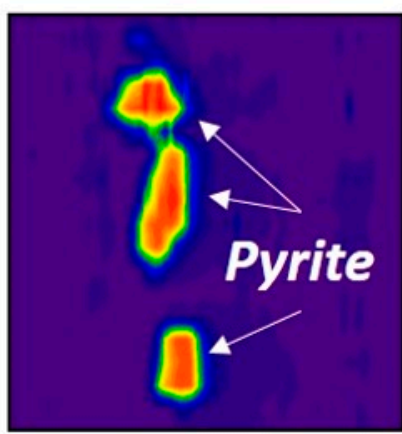

Se

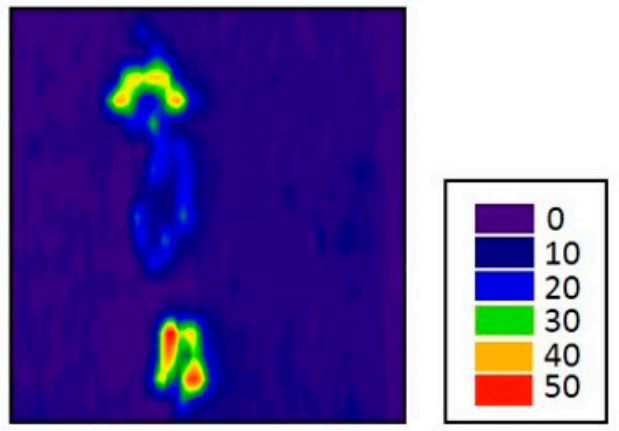

$\mathrm{Hg}$

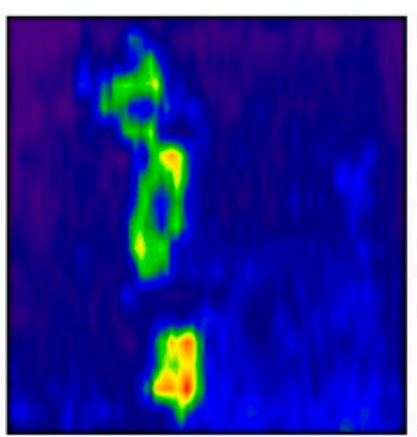

$\mathrm{Pb}$
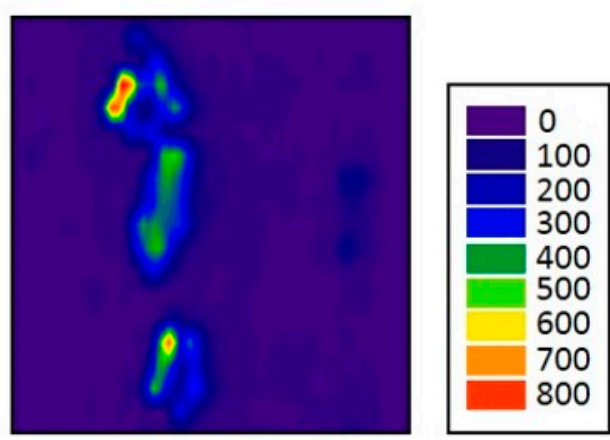

Figure 2. Brora coal, digitised sample and laser ablation inductively coupled plasma-mass spectrometry (LA-ICP-MS) trace element maps. Map size $25 \mathrm{~mm} \times 25 \mathrm{~mm}$. 

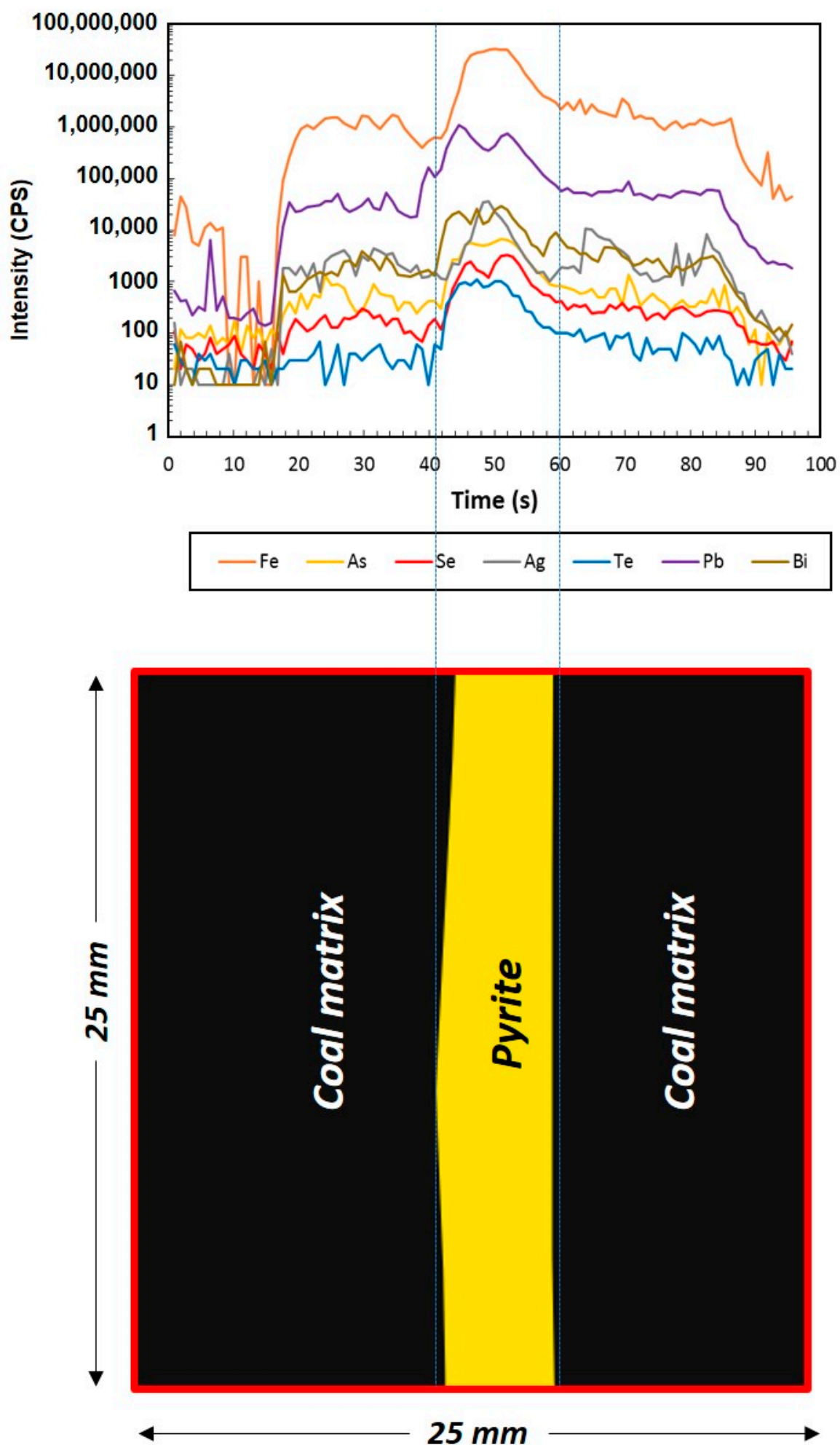

Figure 3. All LA-ICP-MS trace element line transects and corresponding pyrite and coal matrix areas of Brora coal sample (depicted by digitised sample area). 

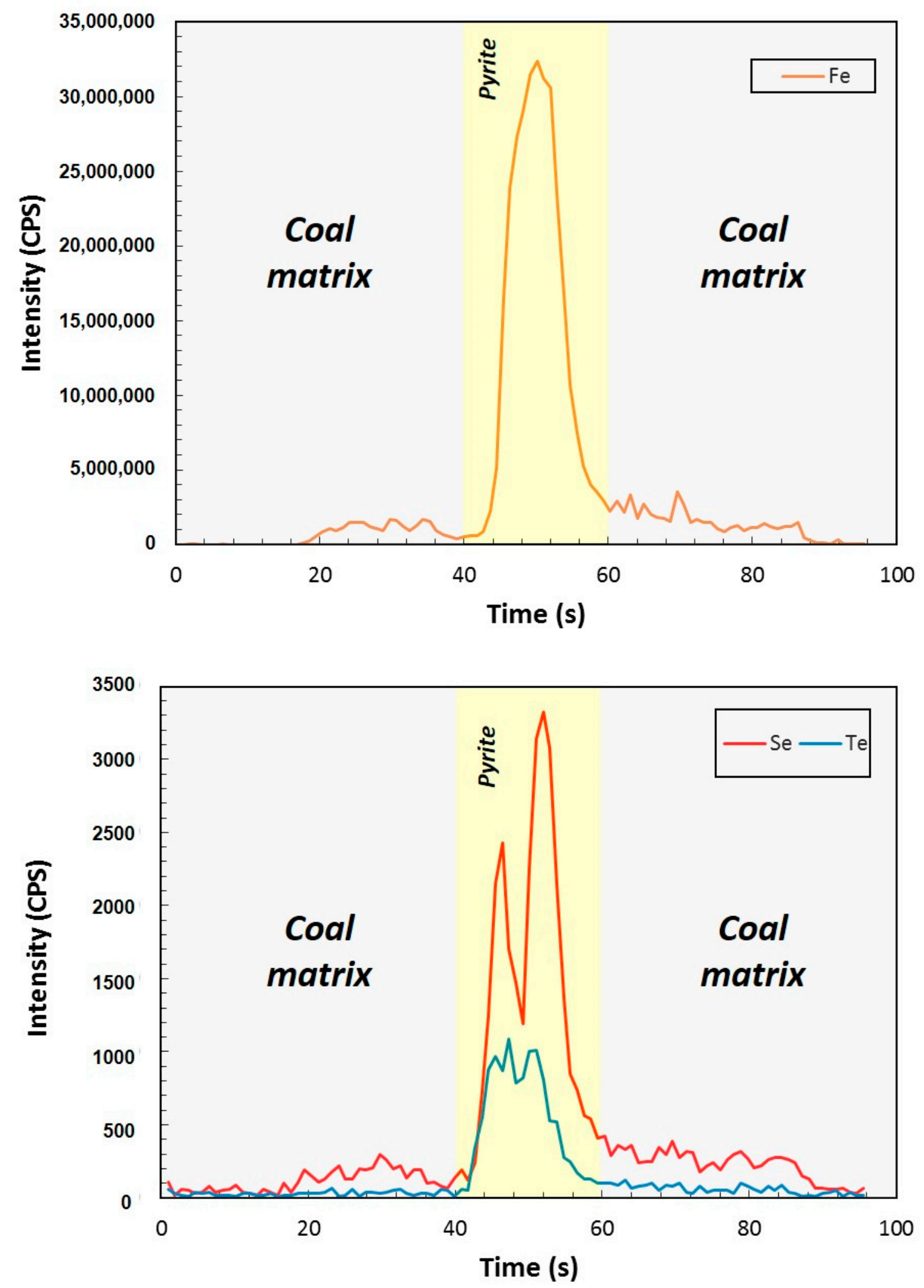

Figure 4. Fe, Se and Te LA-ICP-MS trace element line transects and corresponding pyrite and coal matrix areas of Brora coal sample. Peaks of Se and Te highest towards edges of pyrite zone. 


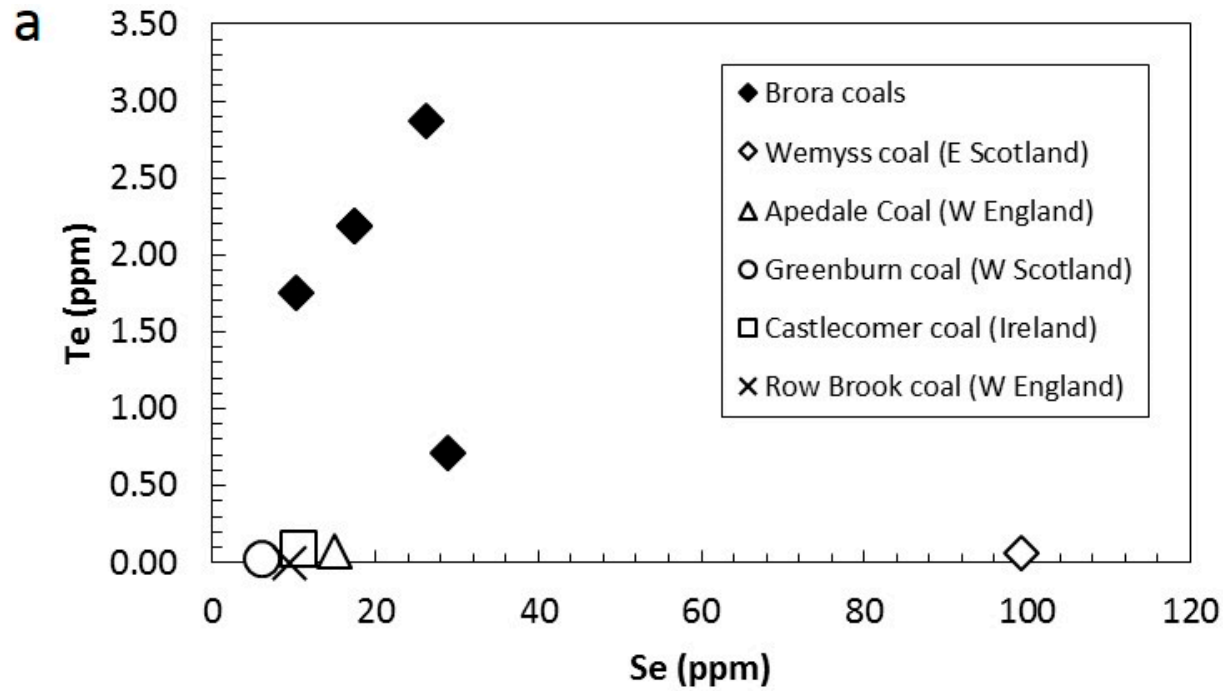

b

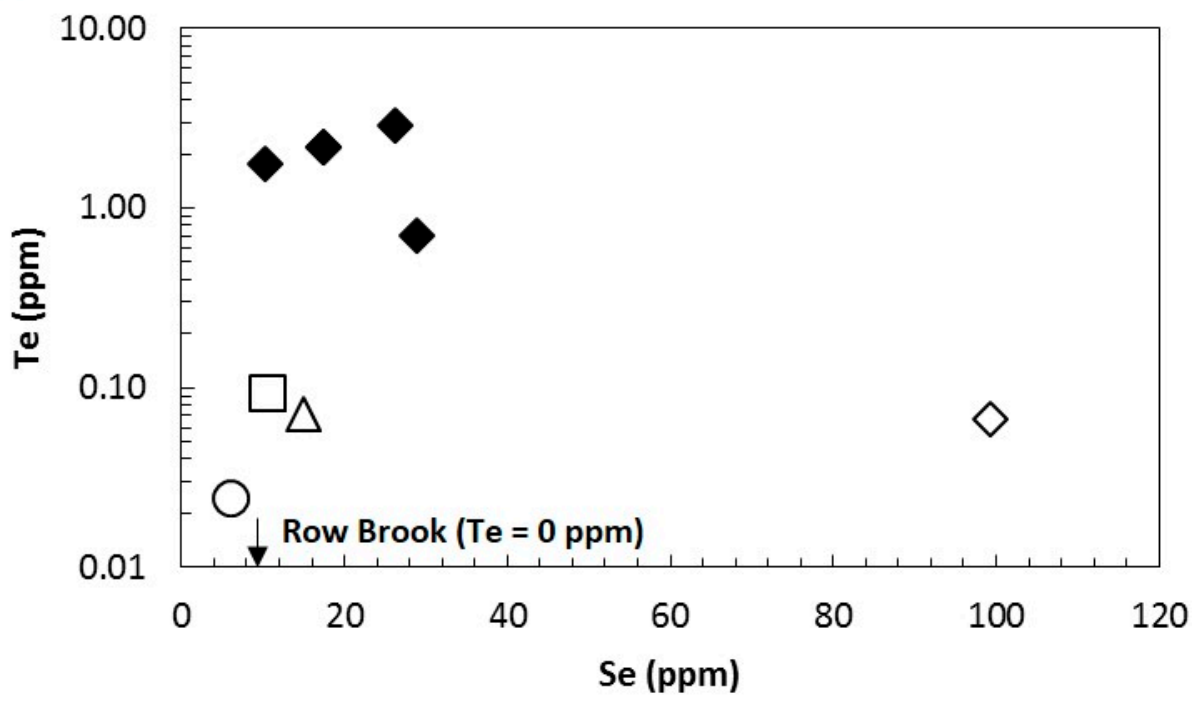

Figure 5. LA-ICP-MS Te vs. Se in pyrite cross-plot showing Brora coal-hosted pyrite compared to other pyrite hosted in British and Irish Carboniferous coals: (a) normal scale; and (b) log scale.

Table 1. Se and Te content (LA-ICP-MS) of Brora Jurassic pyrite, and comparative pyrite in British and Irish Carboniferous coal.

\begin{tabular}{ccccc}
\hline Sample & Age & Se $(\mathbf{p p m})$ & Te $(\mathbf{p p m})$ & Se/Te \\
\hline Brora 1 & Jurassic & 10.3 & 1.8 & 5.8 \\
Brora 2 & Jurassic & 26.2 & 2.9 & 9.1 \\
Brora 3 & Jurassic & 17.4 & 2.2 & 7.9 \\
Castlecomer & Carboniferous & 10.5 & 0.1 & 110.9 \\
Row Brook & Carboniferous & 9.4 & 0.0 & - \\
Wemyss & Carboniferous & 99.2 & 0.1 & 1487.4 \\
Apedale & Carboniferous & 15.1 & 0.1 & 213.3 \\
Greenburn & Carboniferous & 5.9 & 0.0 & 240.3 \\
\hline
\end{tabular}




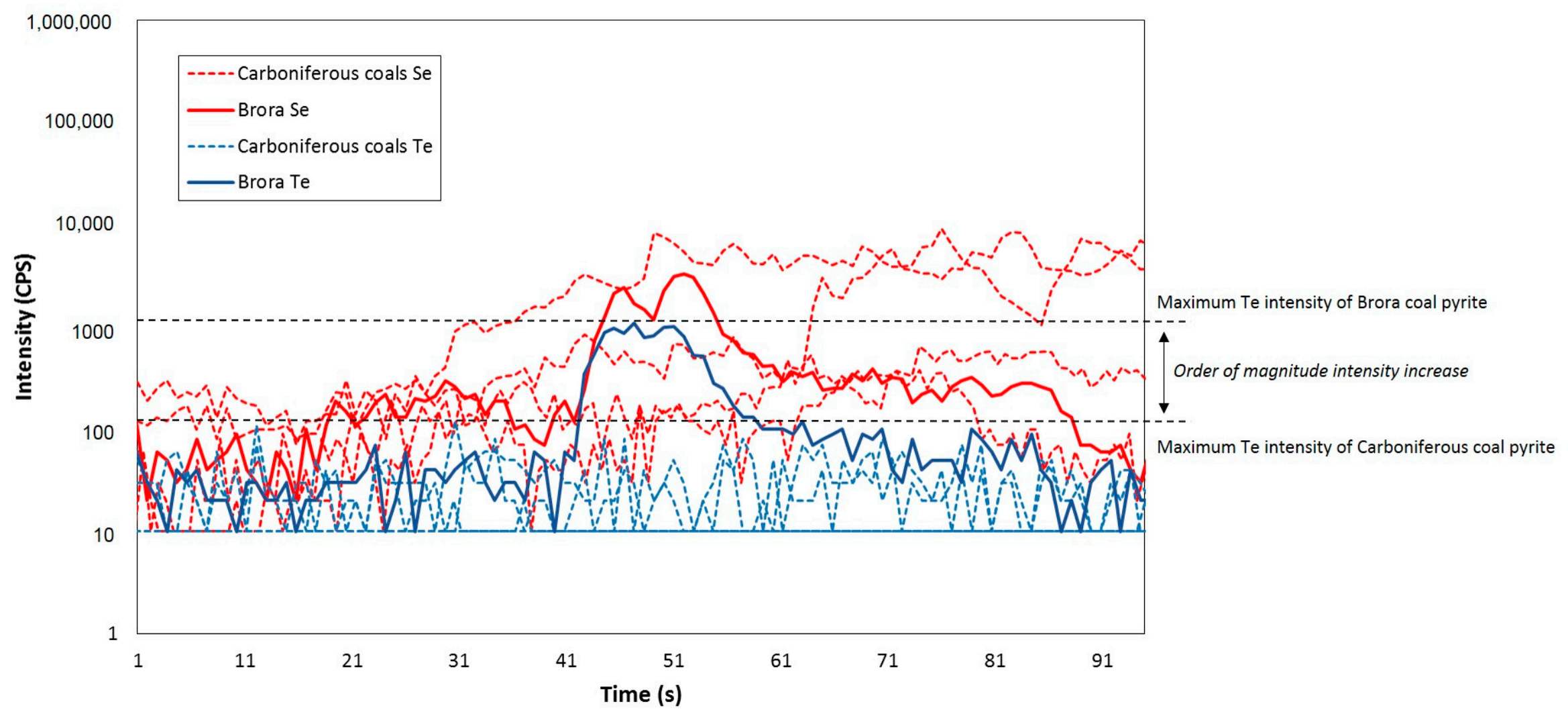

Figure 6. Se and Te LA-ICP-MS trace element line transects for Brora coal pyrite and Carboniferous coals pyrite samples, showing Brora Te peak intensity an order of magnitude higher than Carboniferous coals. 


\section{Discussion}

\subsection{Tellurium in Brora Coal}

LA-ICP-MS methods show Te and other trace element enrichment in band-hosted pyrite. This indicates that sulphide minerals concentrate trace elements in Brora coals, with Te substituting for S. Measured Te content of Jurassic Brora coal pyrite is more than one order of magnitude higher than pyrites of British and Irish Carboniferous coals (Figures 6 and 7; Table 1). Brora coal pyrite also shows a closer relationship between Te and Se compared to the analysed Carboniferous coal pyrite suite, based on LA-ICP-MS line transects (Figure 7), maps and the calculated Se/Te ratio (Table 1). Unlike pyrite in Brora coals, pyritic phases in Carboniferous coals do not show elevated Te content (Figure 7).

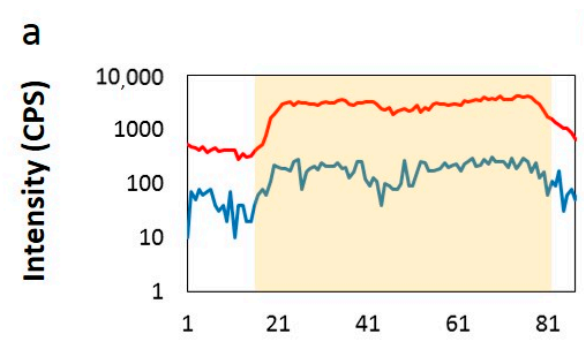

b

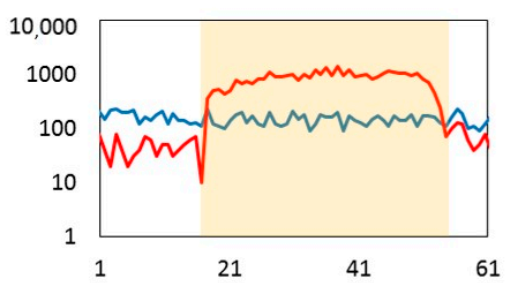

C

d
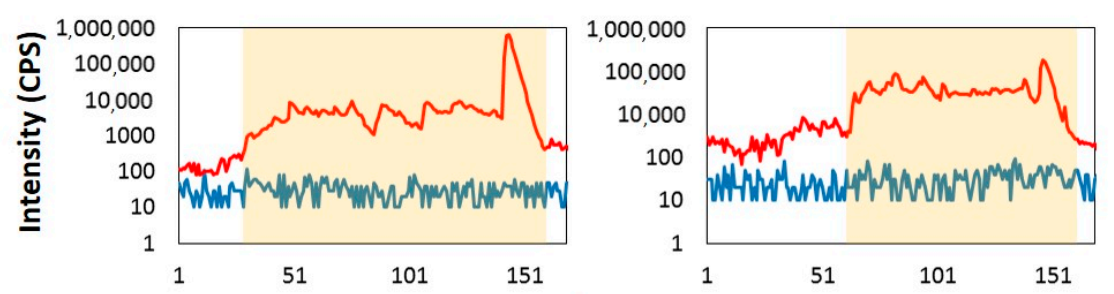

e

$f$
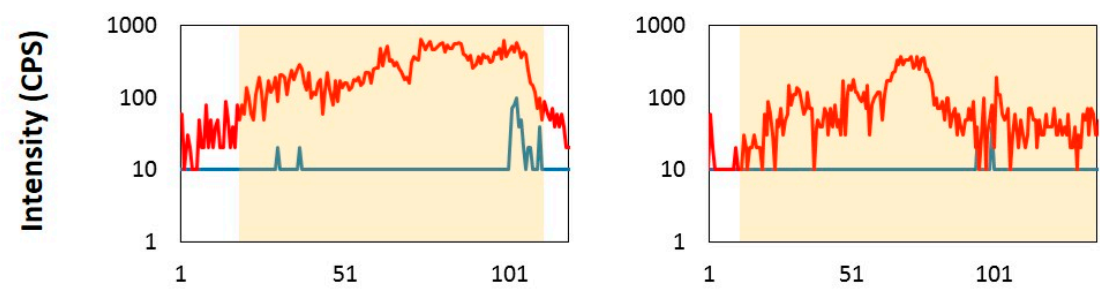

g

h
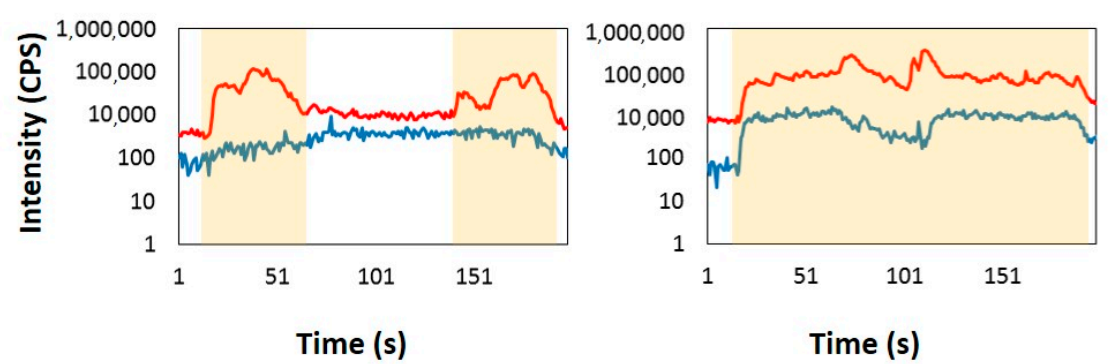

Figure 7. Line transects for British and Irish Carboniferous coals showing low Te (blue line) and no correlation to Se (red line). Pyrite areas shown by yellow shade, indicating that Te shows no strong correlation to pyrite in Carboniferous coals: (a) Castlecomer; (b) Row Brook; (c) Wemyss 1; (d) Wemyss 2; (e) Apedale; (f) Greenburn 1; (g) Greenburn 2; and (h) Greenburn 3. 
Pyrite may have formed by microbial sulphate reduction in coal, contributing to trace element accumulation. Framboidal pyrite has also been observed in Brora coals, indicative of a microbial origin [41,42]. Initial pyrite formation can therefore be attributed to early burial (syn-diagenesis), where marine sulphate is available for microbial sulphate reduction. Based on a subbituminous to bituminous coal ranking, temperatures of coalification likely range $100-150{ }^{\circ} \mathrm{C}$ for Brora coal, suggesting low-temperature $\left(<150^{\circ} \mathrm{C}\right)$ pyrite formation [42,43]. The LA-ICP-MS maps indicate discrete pyrite phases within coal bands, evident by the Fe map (Figure 3). The Te map mirrors that of Se and $\mathrm{Hg}$, with these three elements concentrating in higher abundances at the edges of the larger pyrite phases. By contrast, As and $\mathrm{Cu}$ concentrate in the middle of the pyrite phases. Lead concentrates in some instances in the rim, particularly in Te-rich areas, and in other instances in the centre of the pyrite. These observations suggest that $\mathrm{Fe}, \mathrm{As}, \mathrm{Cu}$ and $\mathrm{Pb}$ were incorporated into pyrite in the early stages of pyrite formation, with higher concentrations of $\mathrm{Te}, \mathrm{Se}, \mathrm{Hg}$ and more $\mathrm{Pb}$ in later pyrite formation, resulting in a rim enriched in these elements. Concentrated areas of Te and Se enrichment may suggest the presence of micro-inclusions of native elemental Te and Se, tellurides and/or selenides, which can also contain $\mathrm{Hg}$ and $\mathrm{Pb}$.

\subsection{Tellurium Source}

The anomalous coal Te content of pyrite in Brora Jurassic coals compared to the British and Irish Carboniferous coals suggests a spatial or temporal Te anomaly. The occurrence of high Te content in pyrite rims also suggest that Te (and other elements such as Se and Hg) formed after the initial onset of pyrite formation by conventional trace element sequestration. High Te in metasedimentary environments have been previously attributed to a magmatic origin and temperatures up to $400^{\circ} \mathrm{C}$ [40], or melting of Te-rich oceanic sediments [44-46]. Potential sources of Te in Brora and the surrounding regions of western Sutherland include Helmsdale Granite (Silurian-Early Devonian) and Old Red Sandstone (Devonian). Alluvial Au deposits are well known in eastern Sutherland, and Au has been identified in the River Brora headwaters near to the town of Brora at the Moray Firth [33,34]. Although no $\mathrm{Au}$ has been identified in Brora coals, some $\mathrm{Au}$ in Brora headwaters occurs as tellurides, and the close affinity between $\mathrm{Te}$ and $\mathrm{Au}[5,42,44-48]$ may point towards a common source. Breccias host pyritic mineralisation (Figure 1a), with previous fluid inclusion studies suggesting a trapping temperature for Au-mineralising hydrothermal fluid of $170-240{ }^{\circ} \mathrm{C}$, indicative of the upper part of the feeder zone to an exhalative hydrothermal system [33]. High-level hydrothermal system feeder zones, similar to the Rhynie Devonian hot-spring locality in Aberdeenshire, are suggested as a potential source for the alluvial Au localities near Helmsdale, and thus may also provide a source for Te and other trace elements to Brora coal. The Brora Coal Formation is cut by the Brora Fault [27], which may have provided a fluid flow pathway for Te and other trace elements from a hydrothermal system.

\subsection{Implications}

Anomalous Te is seldom observed in coal deposits due to low crustal abundance and limited methods of detection [7-10]. While Te in pyritic coal may not be ubiquitous, as evident by the low Te content of pyritic British and Irish Carboniferous coals, Te enrichment is detectable on a microscopic scale by LA-ICP-MS methods. The identification of anomalous Te in coal is also important as enrichment factors of Te are high in airborne particulate matter [49]. Tellurium should therefore be considered in a wider context for coals affected by later trace element enrichment. The presence of previously reported alluvial Au [33], and the identification of anomalous Te in Brora pyritic bands, suggest that Jurassic coals of Brora and sediments in the eastern Sutherland region may contain locally anomalous trace element concentrations. Although Au has not been identified in Brora coals, other local sediments may also host anomalous Te, and possibly Au. Deep pre-glacial weathering and local faulting provide a means of trace element distribution and fluid flow pathways in the 
region, possibly resulting in a wider spread distribution of trace elements associated with local trace element sources.

\section{Conclusions}

Jurassic coals exposed at the town of Brora in northern Scotland contain pyritic bands with anomalous Te content, recognised by LA-ICP-MS methods. Whole rock Brora coal shows Te enrichment compared to estimates of world average Te coal compositions, but more significant Te enrichment occurs in the rims of discrete pyrite phases. Anomalous Te coincides with $\mathrm{Se}$ and $\mathrm{Hg}$ in the pyritic rim, suggesting incorporation of these elements during the later stages of pyrite formation. Anomalous $\mathrm{Te}$ may have been sourced locally from the feeder zone to an analogous epithermal system. This study shows that Te may accumulate locally in pyritic coals, detectable by LA-ICP-MS methods.

Acknowledgments: Funding provided by NERC Security of Supply programme (grant NE/L001764/1). The authors wish to thank three anonymous reviewers for their comments.

Author Contributions: L.B. prepared the manuscript and analyzed the data. J.P. and J.F. conceived the project, undertook the sampling and designed the experiments. M.P. performed the measurements. All authors discussed the results and commented on the manuscript.

Conflicts of Interest: The authors declare no conflict of interest.

\section{References}

1. Rudnick, R.L.; Gao, S. Composition of the continental crust. In The Crust; Rudnick, R.L., Ed.; Elsevier: Amsterdam, The Netherlands, 2003; Volume 3, pp. 1-64.

2. Hein, J.R.; Koschinsky, A.; Bau, M.; Roberts, L. Cobalt-Rich Ferromanganese Crusts in the Pacific. In Handbook of Marine Mineral Deposits; Cronan, D.S., Ed.; CRC Press: Boca Raton, FL, USA, 2000; pp. 239-279.

3. Hein, J.R.; Koschinsky, A.; Halliday, A.N. Global occurrence of tellurium-rich ferromanganese crusts and a model for the enrichment of tellurium. Geochim. Cosmochim. Acta 2003, 67, 1117-1127. [CrossRef]

4. Hein, J.R.; Conrad, T.A.; Staudigel, H. Seamount Mineral Deposits: A Source of Rare Metals for HighTechnology Industries. Oceanography 2010, 23, 184-189. [CrossRef]

5. Spinks, S.C.; Parnell, J.; Bellis, D.; Still, J. Remobilization and mineralization of selenium-tellurium in metamorphosed red beds: Evidence from the Munster Basin, Ireland. Ore Geol. Rev. 2016, 72, 114-127. [CrossRef]

6. Parnell, J.; Spinks, S.; Bellis, D. Low-temperature concentration of tellurium and gold in continental red bed successions. Terra Nova 2016, 28, 221-227. [CrossRef]

7. Castillo, J.R.; Lanaja, J.; Aznárez, J. Determination of germanium in coal ashes by hydride generation and flame atomic-absorption spectrophotometry. Analyst 1982, 107, 89-95. [CrossRef]

8. Nadkarni, R.A. Applications of hydride generation-Atomic absorption spectrometry to coal analysis. Anal. Chim. Acta 1982, 135, 363-368. [CrossRef]

9. Woo, I.H.; Watanabe, K.; Hashimoto, Y.; Lee, Y.K. Determination of Selenium and Tellurium in Coal by Graphite Furnace Atomic Absorption Spectrometry after Coprecipitation with Arsenic. Anal. Sci. 1987, 3, 49-51. [CrossRef]

10. Scherer, V.; Linka, S.; Wirtz, S. Spectral radiation characteristics of coal ashes and slags. Int. J. Energy Clean Environ. 2005, 6, 326-341. [CrossRef]

11. Davidson, D.F.; Lakin, H.W. Tellurium. In United States Mineral Resources; Brobst, D.A., Pratt, W.P., Eds.; US Govt. Print. Off.: Washington, DC, USA, 1973; Volume 820, pp. 627-630.

12. Lottering, C.; Eksteent, J.J.; Steenekamp, N. Precipitation of rhodium from a copper sulphate leach solution in the selenium/tellurium removal section of a base metal refinery. J. S. Afr. Inst. Min. Metall. 2012, 112, 287-294.

13. Pohl, W. Economic Geology: Principles and Practice; Wiley-Blackwell Publishing: Chichester, UK, 2011; p. 695.

14. Schirmer, T.; Koschinsky, A.; Bau, M. The ratio of tellurium and selenium in geological material as a possible paleo-redox proxy. Chem. Geol. 2014, 376, 44-51. [CrossRef] 
15. Templeton, D.M.; Ariese, F.; Cornelis, R.; Danielsson, L.G.; Muntau, H.; van Leeuwen, H.P.; Lobinski, R. Guidelines for terms related to chemical speciation and fractionation of elements. Definitions, structural aspects, and methodological approaches (IUPAC Recommendations 2000). Pure Appl. Chem. 2000, 72, 1453-1470. [CrossRef]

16. El-Shahawi, M.S.; Al-Saidi, H.M.; Al-Harbi, E.A.; Bashammakh, A.S.; Alsibbai, A.A. Speciation and determination of tellurium in water, soil, sediment and other environmental samples. In Speciation Studies in Soil, Sediment and Environmental Samples; Bakirdere, S., Ed.; CRC Press: Boca Raton, FL, USA, 2013; pp. 527-544. [CrossRef]

17. Peiró, T.L.; Méndez, G.V.; Ayres, R.U. Rare and Critical Metals as By-Products and the Implications for Future Supply. In INSTEAD Facility and Research Working Paper; INSEAD: Fontainebleau, France, 2011.

18. Ayres, R.U.; Peiró, T.L. Material efficiency: Rare and critical metals. Phil. Trans. R. Soc. B 2013, 371, 20110563. [CrossRef] [PubMed]

19. Selenium-Tellurium Development Association. Available online: http://www.stda.org/se_te.html (accessed on 24 July 2017).

20. Woodhouse, M.; Goodrich, A.; Margolis, R.; James, T.L.; Lokanc, M.; Eggert, R. Supply-Chain Dynamics of Tellurium, Indium, and Gallium within the Context of PV Manufacturing Costs. IEEE J. Photovolt. 2013, 3, 833-837. [CrossRef]

21. Lusty, P.A.J.; Gunn, A.G. Challenges to global mineral resource security and options for future supply. In Ore Deposits in an Evolving Earth; Jenkin, G.R.T., Lusty, P.A.J., McDonald, I., Smith, M.P., Boyce, A.J., Wilkinson, J.J., Eds.; Geological Society London Special Publications: London, UK, 2014; Volume 393, pp. 265-276. [CrossRef]

22. Chelvanathan, P.; Hossain, M.I.; Amin, N. Performance analysis of copper-indium-gallium-diselenide (CIGS) solar cells with various buffer layers by SCAPS. Curr. Appl. Phys. 2010, 10, 387-391. [CrossRef]

23. Morales-Acevedo, A. Thin film CdS/CdTe solar cells: Research perspectives. Sol. Energy 2006, 80, 675-681. [CrossRef]

24. Lam, K.; Porter, R. The distribution of palynomorphs in the Jurassic rocks of the Brora Outlier, N.E. Scotland. J. Geol. Soc. 1977, 134, 44-55. [CrossRef]

25. Stephen, K.J.; Underhill, J.R.; Partington, M.A.; Hedley, R.J. The genetic sequence stratigraphy of the Hettangian to Oxfordian succession, Inner Moray Firth. In Proceedings of the 4th Conference Petroleum Geology of Northwest Europe, London, UK, 29 March-1 April 1992; Parker, J.R., Ed.; Geological Society: London, UK, 1993; pp. 485-505.

26. MacLennan, A.M.; Trewin, N.H. Palaeoenvironments of the late Bathonian-mid-Callovian in the Innter Moray Firth. In Northwest European Micropalaeontology and Palynology; Keen, M.C., Batten, D.J., Eds.; British Micropalaeontological Society Series; Ellis Horwood: Chichester, UK, 1989; pp. 92-117.

27. Richards, P.C.; Lott, G.K.; Johnson, H.; Knox, R.W.O’B.; Riding, J.B. 3. Jurassic of the Central and Northern North Sea. In Lithostratigraphic Nomenclature of the UK North Sea; Knox, R.W.O'B., Cordey, W.G., Eds.; British Geological Survey: Nottingham, UK, 1993; pp. 77-78.

28. Hurst, A. Mid Jurassic stratigraphy and facies at Brora, Sutherland. Scott. J. Geol. 1981, 17, 169-177. [CrossRef]

29. Linsley, P.N.; Potter, H.C.; McNab, G.; Racher, D. The Beatrice Oil Field, Inner Moray Firth, UK North Sea. In Grant Oil and Gas Fields of the Decade 1968-78; Halbouty, M.T., Ed.; The American Association of Petroleum Geologists: Tulsa, OK, USA, 1980; Volume 30, pp. 117-129.

30. Curry, M.R.; Fisher, M.J. Coastal plain deposits in the Beatrice oilfield, U.K., North Sea (Abstract). In Proceedings of the 11th International Congress of the International Association of Sedimentologists, Hamilton, ON, Canada, 22-27 August 1982; p. 150.

31. Andrews, I.J.; Brown, S. Stratigraphic evolution of the Jurassic, Moray Firth. In Petroleum Geology of North West Europe; Brooks, J., Glennie, K.W., Eds.; Graham \& Trotman: London, UK, 1987; pp. 785-795.

32. Crummy, J.; Hall, A.J.; Haszeldine, R.S.; Anderson, I.K. Potential for epithermal gold mineralization in east and central Sutherland, Scotland: Indications from River Brora headwaters. Metall. Mater. Trans. B 1997, 106, B9-B14.

33. Plant, J.; Coleman, R.F. Application of neutron activation analysis to the evaluation of placer gold concentrations. In Proceedings of the 4th International Geochemical Exploration Symposium, London, UK, 17-20 April 1972; pp. 373-381. 
34. British Geological Survey Geology of Britain Viewer: Online Map Portal. Available online: http:/ /www.bgs. ac.uk/discoveringGeology/geologyOfBritain/viewer.html (accessed on 24 July 2017).

35. Turner, B.R.; Richardson, D. Geological controls on the sulphur content of coal seams in the Northumberland Coalfield, Northeast England. Int. J. Coal Geol. 2004, 60, 169-196. [CrossRef]

36. Bragg, L.J.; Oman, J.K.; Tewalt, S.J.; Oman, C.L.; Rega, N.H.; Washington, P.M.; Finkelman, R.B. U.S. Geological Survey Coal Quality (COALQUAL) Database: Version 2.0; U.S. Geological Survey Open File Report 97-134; The Survey (USGS Distribution Branch): Washington, DC, USA, 1998.

37. Yudovich, Y.E.; Ketris, M.P. Selenium in coal: A review. Int. J. Coal Geol. 2006, 67, 112-126. [CrossRef]

38. Palmer, C.A.; Oman, C.L.; Park, A.J.; Luppens, J.A. The U.S. Geological Survey Coal Quality (COALQUAL) Database Version 3.0; U.S. Geological Survey Data Series; U.S. Geological Survey: Reston, VA, USA, 2015; Volume 975, p. 43. [CrossRef]

39. Spears, D.A. The geochemistry and mineralogy of high-S coals, with examples mainly from the Yorkshire-Nottinghamshire coalfields, UK: An overview. Proc. Yorks. Geol. Soc. 2015, 60, 204-226. [CrossRef]

40. Ketris, M.P.; Yudovich, Y.E. Estimations of Clarkes for Carbonaceous biolithes: World averages for trace element contents in black shales and coals. Int. J. Coal Geol. 2009, 78, 135-148. [CrossRef]

41. Machel, H.G. Bacterial and thermochemical sulphate reduction in diagenetic settings-Old and new insights. Sediment. Geol. 2001, 140, 143-175. [CrossRef]

42. Parnell, J.; Bellis, D.; Feldmann, J.; Bata, T. Selenium and tellurium enrichment in palaeo-oil reservoirs. J. Geochem. Explor. 2015, 148, 169-173. [CrossRef]

43. Orr, W.L. Changes in sulfur content and isotopic ratios of sulfur during petroleum maturation-Study of Big Horn Basin Palaeozoic oils. Am. Assoc. Pet. Geol. 1974, 58, 2295-2318.

44. Afifi, A.M.; Kelly, W.C.; Essene, E.J. Phase relations among tellurides, sulfides, and oxides: II. Applications to telluride-bearing ore deposits. Econ. Geol. 1988, 83, 395-404. [CrossRef]

45. Jensen, E.P.; Barton, M.D. Gold deposits related to alkaline magmatism. Rev. Econ. Geol. 2000, 13, $279-314$.

46. Cook, N.J.; Ciobanu, C.L.; Spry, P.G.; Voudouris, P. The participants of IGCP-486. Understanding gold-(silver)telluride-(selenide) deposits. Episodes 2009, 32, 249-263.

47. Boyle, R.W. The geochemistry of gold and its deposits. Geol. Surv. Can. Bull. 1979, 280, 584.

48. Ciobanu, C.L.; Cook, N.J.; Spry, P.G. Telluride and selenide minerals in gold deposits-How and why? Mineral. Petrol. 2006, 87, 163-169. [CrossRef]

49. Hashimoto, Y.; Watanbe, K.; Yumoto, K.; Otoshi, T. Tellurium as a Possible Tracer of Coal Combustion Effluent. J. Jpn. Soc. Air Pollut. 1989, 24, 45-51. 